\title{
Patent Rights and Local \\ Working Under the \\ WTO TRIPS \\ Agreement: \\ An Analysis of the U.S.- \\ Brazil Patent Dispute
}

\section{Paul Champ ${ }^{\dagger}$ and Amir Attaran ${ }^{\ddagger}$}

I. INTRODUCTION

II. HISTORY OF PATENTS AND LOCAL WORKING REQUIREMENTS ................................................ 370

III. A NEGOTIATING HISTORY OF THE TRIPS AGREEMENT AND LOCAL WORKING .......................... 373

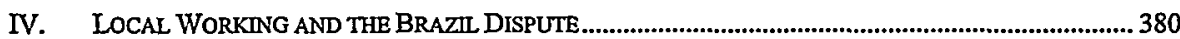

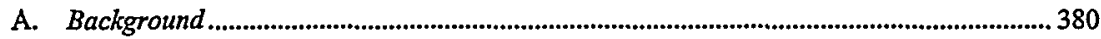

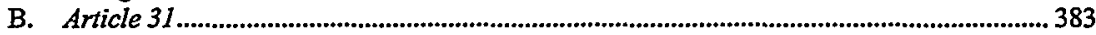

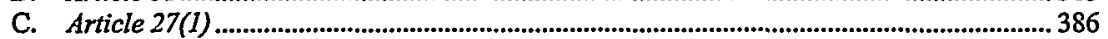

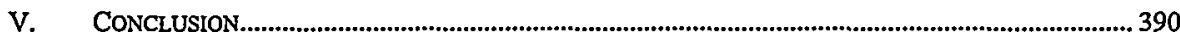

\section{INTRODUCTION}

Before settling a recent WTO dispute with Brazil, the United States Trade Representative (USTR) came perilously close to creating a full-scale public relations disaster for the U.S. government and perhaps for the entire WTO system. ${ }^{1}$ The U.S. challenge concerned a provision of Brazilian patent law $^{2}$ that Brazil says it can use to issue compulsory licenses ${ }^{3}$ for patented

$\dagger$ Attorney, Raven, Allen, Cameron \& Ballantyne, Ottawa, Ontario, Canada; LL.B, University of British Columbia; LL.M., McGill University.

$\ddagger \quad$ Adjunct Lecturer in Public Policy, Kennedy School of Government, Harvard University; D.Phil. Oxford; M.S., California Institute of Technology; LL.B., University of British Columbia.

1. Press Release, Office of the United States Trade Representative, United States and Brazil Agree To Use Newly Created Consultative Mechanism To Promote Cooperation on HIV/AIDS and Address WTO Patent Dispute (June 25, 2001), available at http://usinfo.state.gov/topical/econ/group8 /summit01/01062512.htm [hereinafter USTR]. For the original complaint, see Brazil-Measures Affecting Patent Protection, WT/DS199/3 (Jan. 9, 2001), available at http://www.wto.org.

2. The formerly impugned provision is found at Article 68 of Brazil's Industrial Property Law, Law No. 9,279, May 14, 1996. See http://www.inpi.gov.br/legislacao for the original Portuguese version, or infra note 97 for an English translation.

3. A "compulsory license" refers to a license issued by a government for use of a patent by a party other than the patentee without the consent of the patentee. The Agreement on Trade-Related Aspects of Intellectual Property Rights calls it "[o]ther use without the authorization of the right holder." Agreement on Trade-Related Aspects of Intellectual Property Rights, Apr. 15, 1994, WTO Agreement, Annex 1C, art. 31, in The Legal Texts: The Results of THE URUGUAy Round OF MULTILATERAL TRADE Negotiations 321, 334 (World Trade Organization, 1999) [hereinafter LEgat TEXTS], 33 
AIDS drugs, thereby lowering costs for the drugs the government provides for free to Brazilian AIDS patients. With only months to go before the critical launch of the Doha trade round, and imperiled by an anti-globalization movement in which AIDS activists are some of the most vocal and savvy avatars, the United States probably calculated that it stood to lose more by "winning" this litigation than by abandoning it. ${ }^{4}$

But with the WTO dispute settled on terms that allow the United States to bring a fresh complaint at any time, there is no res judicata, and the legality of statutes such as Brazil's remains in question. A future conflict with Brazil or another developing country looking to compulsory licensing seems almost inevitable.

The U.S. complaint alleged that Brazil's patent law violates the WTO Agreement on Trade-Related Aspects of Intellectual Property Rights (the TRIPS Agreement) ${ }^{5}$ because it authorizes compulsory licensing on the ground of the patentee's failure to work locally (i.e., failure to manufacture the product in the territory of that country issuing the patent). ${ }^{6}$ Such local working requirements, coupled with the remedy of compulsory licensing for failure to work locally, are a fixture in the patent regimes of many countries in the world ${ }^{7}$ and have been since the advent of the patent system. ${ }^{8}$ Even so, in the absence of a definitive WTO ruling on local working, many countries today are being pressured to change their local working laws on the assumption that they violate the TRIPS Agreement. ${ }^{9}$ Legal uncertainty about local working requirements after the TRIPS Agreement is responsible for creating undue friction between WTO member states, and according to the submission of Brazil, is responsible for endangering access to life-saving drugs. ${ }^{10}$

I.L.M. 81 [hereinafter TRIPS Agreement].

4. South Africa passed a law in 1997 permitting the Health Minister to make certain exceptions to the national patent laws and to provide for less-expensive access to patented pharmaceuticals, including AIDS drugs. The United States strenuously objected and threatened to impose unilateral trade sanctions. Adverse public reaction forced the Clinton administration to back down from such pressures. Sara M. Ford, Compulsory Licensing Provisions Under the TRIPS Agreement: Balancing Pills and Patents, 15 AM. U. INT'L L. REV. 941, 950-56 (2000).

5. TRIPS Agreement, supra note 3.

6. The traditional sense of local working is local manufacture. However, some have tried to shift the meaning of the concept to include local commercial use, i.e., making available for local sale, which may be satisfied by importation. G.H.C. BODENHAUSEN, GUIDE TO THE APPLICATION OF THE PARIS CONVENTION FOR THE PROTECTION OF INDUSTRIAL PROPERTY 71 (1968). In this paper, the term will be used in the traditional sense, except when noted.

7. In 1968, with the exception of the United States and the Soviet Union, every industrialized country in the world had local working requirements. J.W. BAXTER, WORLD PATENT LAW AND PRACTICE 117 (1968). By 1993, the situation had changed very little, with the vast majority of countries, industrialized and otherwise, requiring local working, although a few had loosened that requirement by treating importation as satisfactory (e.g., Australia, Hungary, South Korea, and Mexico). See Gianna Julian-Amold, International Compulsory Licensing: The Rationales and the Reality, 33 IDEA 349, $372-$ 95 (1993). Interestingly, the advent of the TRIPS Agreement has not led many countries to amend their local working provisions. In Europe, for example, as recently as 1997 only the Netherlands and Switzerland had changed their laws. BERND HANSEN \& FRITJOFF HIRSCH, PROTECTING INVENTIONS IN CHEMISTRY 406-07 (1997).

8. Michael Halewood, Regulating Patent Holders: Local Working Requirements and Compulsory Licences at International Law, 35 OsGoODE HALL L. J. 243, 251-52 (1997); see also discussion infra Part II.

9. Halewood, supra note 8, at 245 \& n.3.

10. Although the United States initially rejected Brazil's contention that this litigation 
In this Article, we attempt to demystify the legal status of local working as a ground for compulsory licensing in the wake of the TRIPS Agreement. We conclude that local working requirements continue to be generally permissible; that is, failure to work remains a valid ground for which to grant a compulsory license under the TRIPS Agreement, although the TRIPS Agreement somewhat limits the procedure that must be followed. Though there are certainly contrary opinions that the TRIPS Agreement totally prohibits local working requirements, these generally are based on a narrow reading of only a few words in the TRIPS Agreement text, without regard for the document as a whole or its context. " We contend that a more comprehensive analysis of the TRIPS Agreement text, its travaux préparatoires, and the context of patent law history leads to a different conclusion.

The legal arguments for local working can be summarized briefly. Countries' general obligations to grant patents and confer exclusive rights to patent-holders are contained in Articles 27 and 28 of the TRIPS Agreement. ${ }^{12}$ The United States claims that these clauses bar the imposition of a local working requirement and compulsory licensing for failure to work. In particular, Article 27(1) states that patent rights shall be enjoyable without discrimination as between products that are imported or locally produced. However, it is argued here that these clauses are general provisions subject to the specific exceptions contained in Articles 30 and 31 of the TRIPS Agreement, ${ }^{13}$ and possibly Article $5 \mathrm{~A}$ of the related Paris Convention. ${ }^{14}$ In other words, Articles 27 and 28 are general rules, and the exceptions are specific rules. According to well-established principles of legal construction, where a general legal provision conflicts with a specific legal provision, the specific legal provision takes precedence (lex specialis derogat legi generali). Consequently, if the specific exceptions allow compulsory licensing for a

concemed access to AIDS drugs, it had acknowledged this view by the time it settled the case. See infra Part IV.A. It is nevertheless true that the Brazilian local working requirement is facially neutral and applies to patents generally, not only to those for pharmaceuticals. See infra note 97 and accompanying text.

11. See, e.g., Daniel Gervais, The TRIPS Agreement: Drafting ANalysis and NegotiAting History 167 (1998); Martin J. Adelman \& Sonia Baldia, Prospects and Limits of the Patent Provision in the TRIPS Agreement: The Case of India, 29 VAND. J. TRANSNAT'L L. 507, 517 (1996); M. Doane, TRIPS and International Intellectual Property Protection in an Age of Advancing Technology, 9 AM. U. J. INT'L. L. \& POL'Y 465, 479 (1994); George Foster, Opposing Forces in a Revolution in International Patent Protection: The U.S. and India in the Uruguay Round and Its Aftermath, 3 UCLA J. INT'L L. \& FOREIGN AFF, 283, 292 (1998).

12. TRIPS Agreement, supra note 3, art. 27 ("Patentable Subject Matter"), art. 28 ("Rights Conferred'). See infra notes 98 and 99 for full text of these articles.

13. See TRIPS Agreement, supra note 3, art. 30 ("Exceptions to Rights Conferred"), art. 31 ("Other Use Without Authorization of the Right Holder").

14. Paris Convention for the Protection of Industrial Property, Mar. 20, 1883, 828 U.N.T.S. 307 (revised at Brissels on Dec. 14, 1900, at Washington on June 2, 1911, at the Hague on Nov. 6, 1925, at London on June 2, 1934, at Lisbon on Oct. 31, 1958 and at Stockholm on July 14, 1967) [hereinafter Paris Convention (1883); Brussels Revision to Paris Convention (1900); Washington Revision to Paris Convention (1911); Hague Revision to Paris Convention (1925); London Revision to Paris Convention (1934); Lisbon Revision to Paris Convention (1958); Stockholm Revision to Paris Convention (1967)]; see also TRIPS Agreement, supra note 3, art. 2(1) (stating that Members "shall comply" with the substantive provisions of the Paris Convention). For a discussion of the potential application of Article 5A of the Paris Convention, see infra Section IV.C. 
failure to work (which they do), this is dispositive of the general provisions which, if read alone, seem to prohibit it.

That Article 31 on its face would permit compulsory licensing, including licensing for a failure to work, is clear. ${ }^{15}$ The controversial aspect of the argument presented here is the assertion that the exceptions in Articles 30 and 31 govern Article 27. It is agreed by most, if not all, countries that Article 28 is subject to the provisions of Articles 30 and 31. However, several countries maintain that Article 27 is somehow an "absolute" clause, not subject to the exceptions outlined in Articles 30 and $31 .^{16}$ Previous WTO Panel jurisprudence supports the view that Article 27 is absolute, even as it acknowledges, somewhat remarkably, that there is nothing in the text of the TRIPS Agreement to support this assertion; rather, it is simply taken as a "fact" that is "understood."

The idea that words may be assumed or imported into a treaty is contrary to the interpretive rules and principles of public international law. ${ }^{18}$ In another TRIPS Agreement case, the WTO Appellate Body overturned a Panel decision for just this reason, saying that it would not "condone the imputation into a treaty of words that are not there." that Article 27 is absolute, and should not be read subject to Article 31, bears that burden of proof. However, even assuming this interpretation were correct, it is still not clear that local working requirements-adopted on a limited basis for the purposes of promoting technology transfer and economic development-must be prohibited in all circumstances. ${ }^{20}$ The TRIPS

15. Article 31 of the TRIPS Agreement does not limit the grounds for which a compulsory license may be issued. Instead, the provision imposes strict conditions and procedural requirements for such issuance. According to one scholar, "negotiators weighed both options and preferred to leave open the cases where compulsory licensing ... may be allowed." GeRVAIS, supra note 11, at 165 . The fact that the grounds for issuing a compulsory license was left open means that compulsory licensing for failure to work locally is permitted. See discussion of Article 31 infra Section IV.B.

16. These arguments were presented in a WTO case involving a complaint filed by the European Communities that Canada's patent law violated Articles 27 and 28 of the TRIPS Agreement because it permitted stockpiling and regulatory approval of pharmaceuticals before patent expiration. Several countries intervened as third parties, including the United States, Brazil, India, Japan, and Switzerland. Canada claimed that the provisions in question were protected as exceptions permitted by Article 30. All parties agreed that exceptions contained in Articles 30 and 31 applied to Article 28. However, the European Communities and some other industrialized countries disagreed with Canada's position that Article 30 exceptions also applied to Article 27. Switzerland summarized this position by arguing that Article 27 is an "absolute" clause which is not subject to any other provisions. A panel found against Canada on this point. See Panel Report on Canada-Patent Protection of Pharmaceutical Products, WT/DS114/R, I7 7.88-7.93 (Mar. 20, 2000), available at http:/www.wto.org. This case was not appealed to the Appellate Body, and we disagree with the Panel's finding on this issue. See discussion infra Part V.

17. The Panel says that it is an "acknowledged fact" that Article 27 is not subject to the Article 30 and 31 exceptions because it is simply "understood . . . without the need for any textual provision so providing." Panel Report on Canada-Patent Protection of Pharmaceutical Products, supra note 16, ๆ 7.91.

18. See Vienna Convention on the Law of Treaties, opened for signature May 23, 1969, art. 31, 1155 U.N.T.S. 331, 8 I.L.M. 679.

19. Appellate Body Report on India-Patent Protection for Pharmaceutical and Agricultural Chemical Products, WT/DS5O/AB/R, If 45 (Dec. 19, 1997), available at http://www.wto.org.

20. The German Patent Act is worded in such a way. Section 24 of the German Patent Act provides:

If the ... patentee refuses to permit the exploitation of the invention by another ... offering to pay reasonable compensation and to furnish security therefor, that person shall 
Agreement is very clear that technology transfer is a primary objective of the treaty. ${ }^{21}$ Local working is historically recognized as the primary means for effecting this goal, and it should not be lightly presumed that this tool for economic development was terminated by the TRIPS Agreement. ${ }^{22}$

The conclusion that local working continues to be permitted by the TRIPS Agreement is confirmed by an examination of the TRIPS Agreement negotiating history and the travaux préparatoires of the agreement. ${ }^{23}$ Essentially three positions on local working were asserted during the negotiations. Developing countries wanted local working to be a mandatory obligation of any patentee. ${ }^{24}$ That is, the requirement to work locally was not viewed as an exception to patent rights, but rather an essential condition for their conferral. The United States was almost alone at the other end of the spectrum, seeking to bar any possible obligation or remedy there might be for a patentee's failure to work locally. ${ }^{25}$ The European Communities staked out the middle ground, proposing that local working requirements should be a permissible exception to patent rights but not a patentee obligation. ${ }^{26}$ These respective positions were maintained throughout the negotiations, with

be given authority to exploit the invention if the permission is indispensable to the public interest.

Julian-Arnold, supra note 7, at 379 (translated by Julian-Arnold). Brazil could likely circumvent the U.S. complaint and still achieve its objectives by replacing Article 68 of their Industrial Property Law with language similar to the German law. Carlos Correa suggests in a similar fashion that it may be possible to grant compulsory licenses "in qualified cases of lack of working, for instance, when such a lack affects the commercial or industrial development in the country of sectors of vital interest." Carlos M. Correa, Intellectual Property Rights and the USE of Compulsory Licenses: OPTTONS FOR DEVELOPING CoUNTRIES 9 (South Centre Trade-Related Agenda, Development and Equity (TRADE), Working Paper No. 5, 1999).

21. Article 7 of the TRIPS Agreement, supra note 3, titled "Objectives," states that intellectual property rights "should contribute to ... the transfer and dissemination of technology ... in a manner conducive to social and economic welfare." Article 8(2) of the TRIPS Agreement, supra note 3, titled "Principles," notes that "appropriate measures" may be necessary to prevent patent holders from resorting to practices that "adversely affect the international transfer of technology." This article appears to envision measures such as compulsory licensing for unreasonable failure to work.

22. See discussion infra Part II; INTRODUCTION to INTELlECTUAL PROPERTY: THEORY aND PRACTICE 146 (WIPO ed., 1997) [hereinafter INTRODUCTION TO IP] ("The primary goal of requiring local working of patented inventions is the transfer of technology, the actual working of a patented invention in a given country being seen as the most efficient way of accomplishing such a transfer to that country.").

23. Travaux preparatoires is a term referring to the preparatory work of the treaty negotiations, including documents such as proposals, drafts, statements, and reports of negotiation meetings. See Vienna Convention, supra note 18, at 692 (stating that the travaux préparatoires can be used as a "supplementary means of interpretation"); ANTHONY AUST, MODERN TREATY LAW AND PRACTICE 197-99 (2000).

24. Communication from Argentina, Brazil, Chile, China, Colombia, Cuba, Egypt, India, Nigeria, Peru, Tanzania, Uruguay, and Pakistan, part II, chap. II, art. 5, II 2, GATT Doc. MTN.GNG/NG11/W/71 (May 14, 1990) [hereinafter Developing Countries' Draft]. This document is still officially restricted and unavailable on the WTO website; however, it is published in INTELLECTUAL PROPERTY AND INTERNATIONAL TRADE: The TRIPS AgreEment 441 (Carlos M. Correa \& Abdulqawi A. Yusuf eds., 1998) [hereinafter INTELLECTUAL PROPERTY AND INT'L TRADE].

25. See Draft Agreement on the Trade-Related Aspects of Intellectual Property Rights, Communication from the United States, art. 27, GATT Doc. MTN.GNG/NG11/W/70 (May 11, 1990) [hereinafter U.S. Draft], available at http://www.wto.org (stating that the U.S. proposal restricted compulsory licensing to national emergencies and anti-competitive abuses).

26. See Draft Agreement on Trade-Related Aspects of Intellectual Property, Communication from the European Communities, art. 26, GATT Doc. MTN.GNG/NG11/W/68 (Mar. 29, 1990) [hereinafter E.C. Draft], available at http://www.wto.org. 
developing countries and the United States sticking to their preferred local working rules, ${ }^{27}$ and subsequent consensus drafts suggesting that the E.C. position would prevail. ${ }^{28}$ If it really were the parties' intention after so protracted a debate to eliminate local working, one would at least expect to find that remarkable consensus reflected in clear, unambiguous treaty language, such as the United States submitted. But such is not the case.

These arguments will be expanded below. Part II provides a brief history of local working and compulsory licensing and discusses their significance to the development of patent law. This history will examine the Paris Convention and the context of international patent law up to the time of the GATTUruguay Round Negotiations. Part III explores the negotiating history of the TRIPS Agreement. Reference will be made to several party submissions, especially draft agreement texts. Part IV is a substantive analysis of the legality of local working in the context of Brazil's Industrial Property Law. Part V concludes with a discussion about the future of compulsory licensing generally under the TRIPS Agreement.

\section{HISTORY OF PATENTS AND LOCAL WORKING REQUIREMENTS}

The concept of patents ${ }^{29}$ was developed in Europe in the fourteenth and fifteenth centuries as a way for a sovereign to entice skilled artisans and craftspeople from other jurisdictions to move to his or her territory. ${ }^{30}$ The sovereign would grant to the (usually foreign) individual the exclusive privilege of supplying the territory with a certain product. While the individual could become rich without competition, the territory in return hoped it would benefit from developing local expertise through apprenticeships (i.e. technology transfer). The duration of early English patents, fourteen years, reflected the fact that seven years was the standard term of service for apprentices. The foreign master therefore received protection from at least two generations of trainees. ${ }^{31}$ Consistent with the goal of technology transfer, making the product locally was the primary obligation of the patent holder. For England the bargain worked well, as German armorers, Italian shipwrights and glassmakers, French ironworkers, and

27. See discussion infra Part III and, in particular, note 77 and accompanying text.

28. There were two major working drafts developed in 1990. See infra Part III and, in particular, notes 64-74 and accompanying text; see generally GERVAIS, supra note 11 (comparing these two working drafts article by article with the final TRIPS Agreement); 2 THE GATT-URUGUAY ROUND: A NegotiAtING HistoRY (1986-1992), 2286-89 (Terence P. Stewart ed., 1993) [hereinafter GATTURUGUAY ROUND].

29. In English, "patent" is an adjective originally meaning open. The noun form comes from "letters patent," the official documents (or open letters) by which certain privileges, rights, ranks, or titles were conferred and publicly announced. Paul A. David, Intellectual Property Institutions and the Panda's Thumb: Patents, Copyrights, and Trade Secrets in Economic Theory and History, in GloBAL Dimensions of INTEllectual Property Rights IN SCIENCE AND TEChNOLOGY 44 (Mitchel B. Wailerstein et al. eds., 1993).

30. C. MACLEOD, INVENTING THE INDUSTRIAL REVolution: THE ENGLiSH PATENT System, 1660-1800, at 10-11 (1988). In England, for example, some of the earliest letters patent were given to a Flemish weaver in 1331, two Brabant weavers in 1336, and three clockmakers from Delft in 1368. David, supra note 29 , at 45.

31. David, supra note 29 , at 45 . 
Spanish soap-makers were all attracted across the English Channel using patents. ${ }^{32}$

The earliest known statute relating to patents, the Venetian Patent Act of 1474 , provided that a patent would be cancelled if it were not actively exploited. ${ }^{33}$ The United Kingdom Statute of Monopolies in 1623 similarly required local working of a patent as a condition for retaining the patent. ${ }^{34}$ The focus on local industrial development was also apparent in eighteenth century U.S. and French statutes, which provided for patents on foreign inventions only so long as the invention was worked locally. ${ }^{35}$ France would actually revoke a patent grant if the domestic inventor obtained a patent in another country for the same invention. ${ }^{36}$

These examples demonstrate that national self-interest and industrial progress, not protection of the rights of an inventor, were the original rationales for patent systems. However, by the nineteenth century, many countries felt that their interests might be better served by conforming to a more multilateral, standardized regime, which also barred certain excesses such as the automatic forfeiture of a patent for any importation or a failure to work locally. ${ }^{37}$ This fundamental change lies at the heart of the Paris Convention for the Protection of Industrial Property of $1883 .{ }^{38}$ Consequently, the Paris Convention prohibited such automatic forfeiture, even as it affirmed the obligation of patentees to work patents locally where that requirement existed in national law. ${ }^{39}$

The concept of compulsory licensing was not mentioned in the 1883 Paris Convention. ${ }^{40}$ It was introduced as an amendment in the 1925 Hague Revision as a means to restrict the extreme remedy of patent forfeiture in the cases of failure to work or other "abuses which might result from the exclusive rights conferred by the patent. ${ }^{.41}$ Countries were not allowed to

32. Id. at $47-48$.

33. UFF ANDERFELT, INTERNATIONAL PATENT LEGISLATION AND DEVELOPING COUNTRIES 9 (1971).

34. Statute of Monopolies, 1623, 21 Jam. 1, c. 3 (Eng.), in 1 STATUTES REviSED (BRITAIN) HENRY III TO JAMES II, 1253-1685, at 693-96 (1870).

35. Halewood, supra note 8 , at 251-52.

36. INTRODUCTION TO IP, supra note 22 , at 19.

37. Halewood, supra note 8, at 252.

38. The Paris Convention (1883), supra note 14, also created the Union for the Protection of Industrial Property, later known as the United International Bureaux for the Protection of Intellectual Property (BIRPI) in 1883, and finally the World Intellectual Property Organization in 1967. See INTRODUCTION TO IP, supra note 22, at $19,27$.

39. The Paris Convention (1883) states:

The importation by the patentee into the country where the patent has been granted of articles manufactured in any of the States of the Union shall not entail forfeiture of the patent.

...

(2) Nevertheless, the patentee shall remain under the obligation to exploit his patent in accordance with the laws of the country into which he introduces the patented articles. Paris Convention (1883), supra note 14, art. 5, in Halewood, supra note 8, at 284.

40. The concept was discussed as a possibility during the negotiations, but it was not put in the treaty. This was likely because no country at that time had actually used such a measure. See EDITH T. PENROSE, THE ECONOMICS OF THE INTERNATIONAL PATENT SYSTEM 47 (1951). Such a provision was adopted by the Germans in 1877, id. at 166, and the English in 1883, CORREA, supra note 20, at 3.

41. Hague Revision to Paris Convention (1925), supra note 14, art. 5(2), in Halewood, supra note 8, at 285; see also Halewood, supra note 8, at 266-67. 
impose forfeiture unless they had first attempted to remedy the "abuse" through the grant of a compulsory license. ${ }^{42}$ This revision was significant because it gave recognition to failure to work as an "abuse" of international law, for which compulsory licensing was the remedy of first resort. Later, not only did countries identify other abuses (e.g., anti-competitive behavior) that justified compulsory licensing, but they also proposed grounds beyond abuses. Such other grounds are broadly categorized as being in the "public interest," which usually refers to national emergency or public health issues. ${ }^{43}$

The last revisions of the Paris Convention were made in Stockholm in 1967. There was no change with respect to either compulsory licensing or failure to work obligations, though previous amendments were re-affirmed. A compulsory license could not be granted for failure to work before the expiration of three years from the date of the grant of the patent ${ }^{44}$ or four years from the date the patent application was filed. ${ }^{45}$ Such a compulsory license must be non-exclusive and non-transferable. ${ }^{46} \mathrm{~A}$ patent holder can avoid a compulsory license for failure to work by justifying the inaction with "legitimate reasons." ${ }^{, 47}$ Georg Bodenhausen, an eminent authority on the Paris Convention, wrote that legitimate reasons may be legal, economic, or technical obstacles to exploitation. ${ }^{48}$

The Paris Convention remains in force today, and many of its substantive provisions (including those cited here) are incorporated into the TRIPS Agreement by reference. ${ }^{49}$ As a result, even WTO members who are not signatories of the Paris Convention are bound by its obligations.

In summary, the above history demonstrates that local working has consistently been regarded as a fundamental obligation or condition of patent holders, while failure to work has been considered a prima facie "abuse" of the patent privilege under international law. Indeed, until the early 1990s, almost every country in the world had local working requirements. ${ }^{50}$ But in

42. Hague Revision to Paris Convention (1925), supra note 14, art. 5(3), in Halewood, supra note 8 , at 285 .

43. See INTRODUCTION TO IP, supra note 22, at 145, 148-50; CORREA, supra note 20, at 3, 13; BODENHAUSEN, supra note 6, at 70; infra note 52 and accompanying text.

44. Stockholm Revision to Paris Convention (1967), supra note 14, art. 5A(4), in Halewood, supra note 8 , at 287.

45. Id. at 286 (originally appeared in the Lisbon Revision to Paris Convention (1958), supra note 14 , art. $A(4))$.

46. Id.

47. Id. Before compulsory licensing, a patent holder could similarly avoid forfeiture by justifying "his inaction." Washington Revision to Paris Convention (1911), supra note 14, art. 5(2), in Halewood, supra note 8, at 285. Under the Hague Revision to Paris Convention (1925), supra note 14, art. 5(4), the patent holder could avoid compulsory licensing if he or she proved "the existence of legitimate excuses." Id. The "legitimate reasons" language originated in the London Revision to Paris Convention (1934), supra note 14, art. 5(A)(4), in Halewood, supra note 8, at 286. to WIPO.

48. BODENHAUSEN, supra note 6 , at 73. Bodenhausen was the director of BIRPI, the precursor

49. TRIPS Agreement, supra note 3, art. 2(1).

50. In 1993, the vast majority of countries, industrialized and otherwise, required local working. A few countries, such as Australia, Hungary, South Korea, and Mexico, considered importation to satisfy this requirement. The United States and Canada were notable exceptions, though Canada did have a comprehensive compulsory licensing regime. Julian-Arnold, supra note 7, at 372-95. Interestingly, the advent of the TRIPS Agreement has not led to amendments to local working provisions by many countries. In Europe, for example, as recently as 1997 only the Netherlands and Switzerland had changed their laws. HANSEN \& HIRSCH, supra note 7, at 406-07. Indeed, one may 
today's global economy, should local employment and training be a fundamental obligation of all patent holders in all countries? Interestingly, the Paris Convention only mentions compulsory licensing as a remedy for abuses, ${ }^{51}$ but is silent on compulsory licensing for public interest reasons. Bodenhausen states that compulsory licensing on public interest grounds is permitted under the Paris Convention because the treaty is silent on the issue. ${ }^{52} \mathrm{He}$ adds that this question was discussed by the parties in Lisbon in 1958 , and the omission is meaningful. But since failure to work locally was already categorized as an abuse with a clear remedy (compulsory licensing), it is possible that this obviated the need to redefine local working in terms of the "public interest," whether in the Paris Convention or the later TRIPS Agreement. This possibility should be kept in mind when reading the following sections.

\section{A NEGOTIATING HISTORY OF THE TRIPS AGREEMENT AND LOCAL WORKING}

The 1986 ministerial declaration of Punta del Este commenced the Uruguay Round of GATT negotiations. Though intellectual property rights were included in the framework, developing countries preferred to keep primary intellectual property rights obligations under the aegis of the WIPO. They feared that strict standards would deprive them of access to the latest technologies, and thereby increase the gap between North and South. Further, it was felt that the GATT was dominated by industrialized countries, and that their interests would receive insufficient consideration. ${ }^{53}$ Despite their initial resistance, developing countries were eventually compelled to negotiate a comprehensive intellectual property rights agreement under GATT. ${ }^{54}$

wonder why the United States chose Brazil's law to challenge. Speculations on this question, however, are well beyond the scope of this paper.

51. Stockholm Revision to Paris Convention (1967), supra note 14, art. 5A.

52. BODENHAUSEN, supra note 6 , at 70 ("The member states are therefore free to provide analogous or different measures, for example, compulsory licenses on conditions other than those indicated in paragraph (4), in other cases where the public interest is deemed to require such measures.") (emphasis added).

53. See GATT-URUGUAY RoUND, supra note 28, at 2249, 2267; Ana María Pacón, What Will TRIPs Do For Developing Countries?, in FROM GATT To TRIPS-THE AGREEMENT ON TRADERELATED ASPECTS OF INTELLECTUAL PROPERTY RIGHTS 329, 329-32 (Friedrich-Karl Beier \& Gerhard Schricker eds., 1996).

54. The developing countries were forced to negotiate after the United States began imposing unilateral trade sanctions pursuant to the now infamous "Special 301" law. This provision, adopted in 1988 in the U.S. Trade and Competitiveness Act, authorizes the USTR to impose unilateral trade sanctions on countries it declares to be insufficiently protecting intellectual property rights. This law was used during the negotiations in an arbitrary manner that suggests its primary purpose was to influence developing countries in the Uruguay Round negotiations. Ford, supra note 4, at 947; Pacón, supra note 53, at 332; Robert Weissman, A Long, Strange TRIPS: The Pharmaceutical Industry Drive to Harmonize Global Intellectual Property Rules, and the Remaining WTO Legal Alternatives Available to Third World Countries, 17 U. PA. J. INT'L ECON. L. 1069, 1078 (1996). According to the minutes of a June 1991 negotiating meeting, several developing countries expressed frustration with the way the United States used the law throughout the negotiations, claiming that it violated the commitments under the Punta del Este Declaration to not take any measures that would improve negotiating positions. Negotiating Group on TRIPS, Meeting of Negotiating Group of 27 and 28 June 1991, GATT Doc. MTN.GNG/TRIPS/1, II 4-5 (July 25, 1991). Significantly, one participant added that "unilateral actions as taken by the United States under 'Special 301' confirmed his delegation's apprehension of what would happen if a balanced outcome of the TRIPS negotiations was not achieved." Id. I 5. 
As was explained in the Introduction to this Article, three views were advanced in the negotiations with respect to local working. Developing countries wanted local working to be a mandatory patentee obligation, the European Communities wanted local working as an exception to patent rights, and the United States wanted it prohibited. Ordinarily the negotiating process would square these views against one another, until a clear consensus of the parties gradually emerged. For most of the negotiating process, this is exactly what happened: some agreements were reached and set in writing, while disagreements remained in "bracketed text" to be considered at future negotiations. Thus, the negotiating drafts indicate where consensus was reached, and where it remained elusive-except, ironically, for the final draft, which was not negotiated but instead arbitrated by the GATT secretariat. The true intentions of the parties at the conclusion of the TRIPS Agreement are therefore difficult-if not impossible- to discern.

In early 1990, there was still no single TRIPS Agreement draft text that all parties were considering. The Developing Countries' Draft ${ }^{55}$ contained a provision regarding specified obligations of a patent applicant that was eventually incorporated into the final TRIPS Agreement as Article 29, titled "Conditions on Patent Applicants." Both the Developing Countries' Draft and the actual Agreement provided, in almost identical language, that a patent applicant must fully disclose the invention and give information regarding corresponding foreign applications or grants. ${ }^{56}$ In addition, the Developing Countries' Draft contained two further obligations:

(iii) to work the patented invention in the territory of the Party granting it within the time limits fixed by national legislation and subject to the sanctions provided for in chapter VI;

(iv) in respect of licence contracts and contracts assigning patents, to refrain from engaging in abusive or anti-competitive practices adversely affecting the transfer of technology subject to the sanctions provided for in chapters VI and VII. ${ }^{57}$

In other words, the developing countries wanted it clearly stated that, in return for receiving a patent, all patent holders must be expected to work a patent locally. This emphasis was consistent with developing countries' desire to effect technology transfer. ${ }^{58}$ The local working rule was reiterated at a negotiating meeting on November 1, 1990, during which a spokesperson for the developing countries said that the proposed article on conditions for applicants should:

Clearly specify that working the patented invention in the country of grant was one of the obligations of a patentee. Such working was an essential element upon which the patent system was based, and was part of the balance between the interests of patent owners and those of the country undertaking to protect inventions. ${ }^{59}$

55. Developing Countries' Draft, supra note 24.

56. Id. ch. II, art. 5(2); TRIPS Agreement, supra note 3, art. 29.

57. Developing Countries' Draft, supra note 24, ch. II, art. 5(2).

58. WIPO has recognized that the primary goal of local working requirements is effecting the transfer of technology. See INTRODUCTION TO IP, supra note 22, at 146.

59. GERVAIS, supra note 11, at 66-67 (emphasis added); see also TRIPS Agreement, supra note 3, art. 29 ("Conditions on Patent Applicants"). 
In contrast, neither the E.C. Draft nor the U.S. Draft called for a similar obligation on patentees. The European Communities, however, did consider that local working requirements should be available to countries within their national laws, and that these could be a limited exception to patent rights. The E.C. Draft addressed this issue within the scope of its proposal on compulsory licensing, the predecessor to Article 31 in the TRIPS Agreement, which read:

Compulsory Licences: Where the law of a contracting party allows for the grant of compulsory licences, such licences shall not be granted in a manner which distorts trade, and the following provisions shall be respected.

4) Compulsory licences may not be issued for non-working or insufficiency of working on the territory of the granting authority if the right holder can show that the lack or insufficiency of local working is justified by the existence of legal, technical or commercial reasons. ${ }^{60}$

The E.C. Draft was therefore permissive in its approach. While it stopped short of imposing local working as an obligation of the patentee, it left scope for national laws that require local working, subject to considerations of reasonableness that could excuse local working where legitimate reasons for non-working exist.

But even this amount of latitude was overly permissive for the United States, which took the hardest line on the issue. Not only did the U.S. Draft impose no obligation of local working on patentees, as developing countries sought, but it also totally barred compulsory licensing as a remedy for a patentee's failure to work locally, which the E.C. proposal expressly allowed. Thus a failure to work locally would have no adverse consequence for the patentee. The U.S. article on compulsory licensing read:

Contracting parties may limit the patent owner's exclusive rights solely through compulsory licenses and only to remedy an adjudicated violation of competition laws or to address, only during its existence, a declared national emergency. ${ }^{61}$

In short, the United States was proposing that there be only two permissible grounds for compulsory licensing: anti-competition violations and declared national emergencies. By comparison, the E.C. Draft was quite different because it did not restrict the available grounds for issuing a compulsory license, but instead stipulated procedures and conditions for such issuance.

This difference did not go unnoticed during the negotiations, and, in meetings held May 14-16, 1990, the E.C. representative expressed doubts about the restrictive U.S. approach to grounds for compulsory licensing. ${ }^{62}$ Other unnamed participants noted that they preferred the E.C. "structure and approach" to the question of compulsory licensing, "in particular its focus on

60. E.C. Draft, supra note 26 , art. 26.

61. U.S. Draft, supra note 25, art. 27. The text can also be seen in INTELLECTUAL PROPERTY AND INTERNATIONAL TRADE, supra note 24, at 429.

62. Negotiating Group on TRIPS, Meeting of Negotiating Group of 14-16 May 1990, GATT Doc. MTN.GNG/NG11/21, 『13 (June 22, 1990). 
conditions attached to the grant of a compulsory license. ${ }^{.63}$ Left to their own devices to negotiate, there is no record of the parties reaching consensus on any of their differences over local working.

To break this impasse, the Chairman of the TRIPS Agreement negotiating group, Ambassador Lars Anell of Sweden, submitted a draft text in July 1990 that attempted to incorporate the diverse positions of the negotiating group. ${ }^{64}$ This Chairman's Draft tried to reconcile the different views on compulsory licensing with a two-part article that listed grounds and procedures separately. ${ }^{65}$ In addition to anti-competition and national emergency, the Chairman's Draft permitted compulsory licensing for failure to work, ${ }^{66}$ dependent patents, ${ }^{67}$ and the "overriding public interest." ${ }^{68}$ The Chairman's Draft also retained language asserting that local working is an obligation of all patent applicants, subject to requirements in national law. ${ }^{69}$ On these issues, then, the Chairman's Draft more nearly mirrored the Developing Country Draft and the E.C. Draft than it did the U.S. Draft.

Throughout the fall of 1990, there were increasingly intensive negotiations on a possible draft TRIPS Agreement. Ministers from the various countries were scheduled to meet in December 1990, and it was expected that all negotiating groups would have draft agreements completed. Despite persistent differences, the TRIPS Agreement negotiating group was able to submit a consensus draft to the Ministers in Brussels on December 3, 1990. ${ }^{70}$

The Brussels Draft ended up being modeled closely on the Chairman's Draft, and like that document, it reflected the persistence and success of

63. Id. I 22 ("The view was also expressed that the grounds for the granting of compulsory licences had been too narrowly defined and failed to take into account the circumstances of developing countries. . . . It was suggested that they should include national defence, public interest and nonworking.").

64. GATT-URUGUAY ROUND, supra note 28, at 2274 (referring to the Chairman's Report to the GNG on the Status of Work in the Negotiating Group, GATT Doc. MTN.GNG/NG11/W/76 (July 18,1990 ) [hereinafter Chairman's Draft], available at http://www.wto.org). 163-64.

65. Chairman's Draft, supra note 64, pt. III, $\S 5$, arts. 5A.2-.3; GERVAIS, supra note 11, at

66. Chairman's Draft, supra note 64, pt. III, § 5, art. 5A.2.4:

In the event [of failure to exploit the patented invention or that its exploitation] [that the acts of manufacturing, selling or importing of the patented product or using of the patented process and the performance of any of these acts regarding the product obtained by the process] does not satisfy the [basic] needs of the local market before the expiration of a period of four years from the date of the patent application, or three years from the date of the grant of the patent, whichever period expires last, [unless legitimate reasons as viewed from Government's regulation or normal commercial practices exist].

67. Chairman's Draft, supra note 64, pt. III, $\S 5$, art. 5A.2.3. Dependent patents are patents that require the use of another patented product or process and are expressly permitted in the TRIPS Agreement. See TRIPS Agreement, supra note 3, art. 31(1).

68. Chairman's Draft, supra note 64 , pt. III, $\S 5$, arts. 5A.2.2b-.2c. (stating that compulsory licensing is permitted "[o]n the grounds of the public interest concerning national security, critical peril to life of the general public or body thereof" and "[w] here the exploitation of the patented invention is required by reason of an overriding public interest").

69. Chairman's Draft, supra note 64 , pt. III, $\S 5$, art. 3.3B (requiring the owner of the patent "to work the patented invention in the territory of the Party granting it within the time limits fixed by national legislation"); see also GERVAIS, supra note 11, at 156 (giving the same text with different numbering).

70. See GATT-URUGUAY RouND, supra note 28, at 2275 (noting the submission of the Draft Final Act Embodying the Results of the Uruguay Round of Multilateral Trade Negotiations, GATT Doc. MTN.TNC/W/35/Rev.1 (Dec. 3, 1990) [hereinafter Brussels Draft]). 
developing countries in persuading the other parties to maintain a balance of rights and obligations for patentees. ${ }^{71}$ Proposals originating in the Developing Countries' Draft making technological and economic development a defining principle of intellectual property law and placing certain obligations on patentees were much in evidence in the Brussels Draft, and even in the final TRIPS Agreement. ${ }^{72}$ Though heavily bracketed, the Brussels Draft also appeared to retain the developing countries' proposal to make local working a mandatory obligation of patentees. That article read:

PARTIES may provide that a patent owner shall have the following obligations:

(a) To ensure the [working] [exploitation] of the patented invention in order to satisfy the reasonable requirements of the public. [For the purposes of the Agreement the term "working" may be deemed by PARTIES normally to mean manufacture of a patented product or industrial application of a patented process and to exclude importation.] $]^{73}$

Added to this, the compulsory licensing article in the Brussels Draft made reference to local working, and adopted the approach first proposed in the E.C. Draft by imposing procedural limitations but no substantive constraints on the grounds for which a compulsory license could be issued. Compulsory licenses to remedy a failure to work were therefore specifically provided for, in unbracketed (i.e., consensus) text, when the Brussels Draft was agreed to among the negotiating parties:

\begin{abstract}
Authorisation by a PARTY of such use (i.e. compulsory licensing) on grounds of failure to work or insufficiency of working of the patented product or process shall not be applied for before the expiration of a period of four years from the date of filing of the patent application or three years from the date of grant of the patent, whichever period expires last. Such authorisation shall not be granted [where importation is adequate to supply the local market or] if the right holder can justify failure to work or insufficiency of working by legitimate reasons, including legal, technical or economic reasons. ${ }^{74}$
\end{abstract}

This passage can be interpreted in two ways. If only the consensus wording is read, without the bracketed text, it is functionally identical to Article 5A(4) of the Paris Convention, which also provides a three to fouryear grace period before a compulsory license may be granted for failure to work. Given that the Brussels Draft incorporated that Article of the Paris Convention by reference, ${ }^{75}$ this compulsory licensing article would appear to be mere surplusage. But if one reads the whole passage, including the bracketed text, and if one assumes that there was a consensus on the bracketed text, then a failure to work would not trigger a compulsory license when importation can satisfy the local market. In other words, under this interpretation of the provision, even if the definition of failure to work would

71. See GATT-URUguay Round, supra note 28 , at $2783-93$. The Brussels Draft and the Chairman's Draft are compared article-by-article with the final TRIPS Agreement in GERVAIS, supra note 11.

72. Compare Developing Countries' Draft, supra note 24 , pt. II, arts. 1, 2, 5(2), with TRIPS Agreement, supra note 3, arts. 7, 8, 30, 40.

73. Brussels Draft, supra note 70, art. 30 (brackets in original).

74. Id. art. 34. In this paragraph, the square bracketed text is in the original, and the round bracketed text is the authors' addition.

75. Id. art. 30 . 
not change, its consequences would significantly change as compared to the Paris Convention.

Unfortunately, no consensus was reached in Brussels on this point, and when the Uruguay Round negotiations broke down in Brussels on December 7, 1990, all the fruits of the negotiations slid toward jeopardy. In February 1991, the parties decided to restart the Round, and they organized into negotiating groups once again. The new negotiating group on the TRIPS Agreement met for the first time at the end of June 1991, and generally agreed that the Brussels Draft should be the basis for further negotiations. ${ }^{76}$

Thus when negotiations restarted, the views on local working remained as they were reflected in the Brussels Draft: local working should be a mandatory obligation of patentees, and compulsory licensing should definitely be an available remedy for failure to work, with doubts (in bracketed text) about whether importation might be sufficient in lieu of manufacture. The minutes of the negotiations up to December 1991 do not indicate in any way that the parties were entertaining the complete prohibition of local working requirements. Developing countries continued to emphasize in negotiating group meetings from October through early December 1991 that local working "which could not be eluded by importation" was an issue of "fundamental importance" for achieving a final agreement. ${ }^{77}$

Negotiators came under pressure to conclude the TRIPS Agreement by the end of 1991. With just over a month to go, Arthur Dunkel, the director general of the GATT and chairman of the Trade Negotiating Committee, distributed a paper giving his overview of the negotiations and listing the challenges that remained ahead for negotiators. He noted that the "parties needed to determine the availability of patents without discrimination with regard to ... whether the product is imported or locally produced., ${ }^{, 78}$ Thus, both the characterization of local working as possibly "discriminatory" and the exact wording in the TRIPS Agreement which might prohibit it $^{79}$ originated with Director General Dunkel and not the negotiating parties, who were earlier sharply divided on whether importation, and not just manufacture, might be sufficient to meet patentee obligations under the new agreement. The concept of non-discrimination, in other words, did not emerge from any party's negotiating position.

Alert to the end-of-year urgency to conclude an agreement, Chairman Anell declared on December 9, 1991, that intensive, ongoing consultations should take place with a view to settling all outstanding differences. ${ }^{80}$

76. See GATT-URUGUAY RoUND, supra note 28 , at 2277.

77. Negotiating Group on TRIPS, Minutes of Meeting of 16 and 22 October 1991, GATT Doc. MTN.GNG/TRIPS/3, I 9 (Nov. 18, 1991), available at http://www.wto.org. See also Negotiating Group on TRIPS, Minutes of Meeting of 25 and 29 November 1991, GATT Doc. MTN.GNG/TRIPS/4, I 7 (Dec. 9, 1991), available at http://www.wto.org; Negotiating Group on TRIPS; Minutes of Meeting of 9 December 1991, GATT Doc. MTN.GNG/TRIPS/5, I 3 (Jan. 31, 1992), available at http://www.wto.org.

78. GATT-URUGUAY ROUND, supra note 28, at 2279 (paraphrasing Arthur Dunkel, Progress of Work in Negotiating Groups: Stock-Taking, GATT Doc. MTN.TNC/W/89Add.1 (Nov. 7, 1991), available at http://www.wto.org).

79. Director General Dunkel's wording was carried forward verbatim into Article 27(1) of the TRIPS Agreement.

80. Chairman Lars Anell's declaration is noted in Negotiating Group on TRIPS, Meeting of 
Negotiators met regularly over the next week to do just that. Their efforts were not very successful: no further negotiated consensus emerged from those meetings.

At last, the secretariat, Chairman Anell, and Director General Dunkel prepared a new document that essentially arbitrated the outstanding issues. ${ }^{81}$ On December 20,1991, this arbitrated draft was included as part of the Draft Final Act Embodying the Results of the Uruguay Round of Multilateral Trade Negotiations. ${ }^{82}$ Compared to the negotiated Brussels Draft text, the arbitrated draft excised all reference to local working, from both the "Conditions on Patent Applicants" article and the compulsory licensing article. Instead, Director General Dunkel's language on non-discrimination resurfaced in Article 27 under the heading of "Patentable Subject Matter," which states that "patents shall be available and patent rights enjoyable without discrimination as to the place of invention, the field of technology and whether products are imported or locally produced. ${ }^{, 83}$

This arbitrated draft was presented to the parties as a take-it-or-leave-it compromise. Though GATT negotiations carried on until the end of 1993, the arbitrated draft on intellectual property from December 1991 was left virtually unchanged, and, in all respects having to do with local working, this version was adopted in the final TRIPS Agreement. ${ }^{84}$

In retrospect, it is unfortunate that there are no official documents to indicate what the parties believed this eleventh-hour, arbitrated draft signified for local working. ${ }^{85}$ There are reports asserting that India argued for wording that would require patent holders to establish manufacturing facilities in a territory to work a patent, but these reports are unofficial and inconclusive. ${ }^{86}$ The only clear conclusion to be drawn is that developing countries did not succeed in making local working an affirmative obligation of patentees, although this in itself is not dispositive of the issues in a case such as the U.S.Brazil dispute.

The situation is no less ambiguous for compulsory licensing. The arbitrated draft allowed for compulsory licensing without regard to grounds, thus repudiating the U.S. position which sought to allow compulsory licenses only for national emergencies or anti-competition violations (curiously, the latter limitation resurfaced in the final TRIPS Agreement, but only for semiconductor technology, discussed below). ${ }^{87}$ It is harder to know what to

Negotiating Group of 9 December 1991, GATT Doc. MTN.GNG/TRIPS/5, I 1 (Jan. 31, 1992), available at http://www.wto.org.

81. See GERVAIS, supra note 11, at 24; GATT-URUGUAY ROUND, supra note 28, at 2282.

82. GATT Doc. MTN.TNC/W/FA (Dec. 20, 1991), reprinted in GERVAIS, supra note 11, at Annex 10.

83. TRIPS Agreement, supra note 3, art. 27(1) (emphasis added).

84. GERVAIS, supra note 11, at 25; GATT-URUGUAY ROUND, supra note 28, at 2284.

85. The notes from the final official meeting of the TRIPS Agreement Negotiating Group do not reveal what the delegations thought about this arbitrated final draft. See Negotiating Group on TRIPS, Meeting of Negotiating Group of 16 December 1991, GATT Doc. MTN.GNG/TRIPS/6 (Jan. 9, 1992), available at http://www.wto.org.

86. See GATT-URUGUAY ROUND, supra note 28, at 2286-87 (referring to the publication Inside U.S. Trade as the source of the report on the India objection); GERVAIS, supra note 11, at 25 (referring to India's position, but without citation). It seems likely that Gervais relied on GATTURUGUAY ROUND, as he does so frequently in other places.

87. TRIPS Agreement, supra note 3, art. 31(c). 
make of the omission of the Brussels Draft article on failure to work. Is the reason for this omission that the article was duplicative of Article $5 \mathrm{~A}(4)$ of the Paris Convention and therefore surplusage, or is the omission a meaningful abolition of permissive language allowing compulsory licensing for failure to work? The latter interpretation does not fit with the concurrent insertion of a compulsory licensing article unlimited by grounds, and thus seems unlikely.

Most unfortunately, in dropping the Brussels Draft article wholesale, the arbitrated draft deprived negotiators of the opportunity to decide the one issue that remained in bracketed text: whether importation would satisfy "local working" in lieu of local manufacture. The wording invented by Director General Dunkel, making patent rights enjoyable without discrimination as between imported and locally manufactured products, lacks the certainty of a negotiated consensus, and has no forerunner in any earlier negotiated text. Thus, that wording in the final TRIPS Agreement cannot signal anything about the negotiators' intentions, and certainly not in the way that a genuine consensus on including, or excluding, the bracketed text of the Brussels Draft would have done.

In short, one is left to wonder about the intentions of the parties because the final draft was essentially an arbitration-and a sloppy one at that. The analysis in the next Part will look at the agreement as a whole and attempt an interpretation.

\section{LOCAL WORKING AND THE BRAZIL DISPUTE}

\section{A. Background}

The U.S.-Brazil litigation began in May 2000, when the American pharmaceutical industry succeeded in persuading the Clinton administration to take up its fight against local working, which it considered an "objectionable provision [that] mars an otherwise good system" of Brazilian patent protection. ${ }^{88}$ But the legalities were soon lost in politics. Throughout 2000, the litigation languished as AIDS activists kept watch on Vice President Gore, whom they had attacked earlier in his presidential campaign over the Clinton administration's bonhomie with the pharmaceutical lobby. It was only in January 2001, after Gore's failed presidential bid, that the lame-duck Clinton administration requested a WTO Panel hearing.

This was met with dismay in Brazil, where the government-run AIDS program was considered remarkably successful for offering AIDS patients free antiretroviral drugs. To make this possible, the Brazilian Ministry of Health had worked aggressively to lower the cost of anti-retrovirals through a strategy of local manufacture for those products not under patent and

88. Press Release, Pharmaceutical Research and Manufacturers of America, PhRMA Applauds USTR Action Against Argentina and Brazil (May 1, 2000), available at http://www.phrma.org. The USTR announced its intention to seek WTO dispute settlement consultations with Brazil on the same date. Press Release, Office of the United States Trade Representative, USTR Releases Super 301, Special 301 and Title VII Reports (May 1, 2001), available at http://www.ustr.gov/releases/2000/05/index.html. The action was formally commenced by a communication dated May 30, 2000. Brazil-Measures Affecting Patent Protection, WTO Doc. WT/DS199/1G/L/385/IP/D/23 (June 8, 2000), available at http://www.wto.org. 
negotiations with the rights-holder where patents existed. When those negotiations stalled, the Ministry of Health announced that, despite the WTO litigation, Brazil would compulsorily license two anti-retrovirals, efavirenz and nelfinavir, for local manufacture unless they were discounted by $50 \%{ }^{89}$ As one American trade official complained, the Brazilians "clearly decided that the best defense is a good offense." 90

The United States and Brazil signed an agreement settling their WTO patent dispute in June 2001..$^{91}$ The reason for doing so had nothing to do with international patent law and everything to do with politics. After testily denying that the dispute bore any relation to Brazil's quest for access to AIDS drugs ("Nothing could be further from the truth."), ${ }^{92}$ the U.S. Trade Representative Robert Zoellick did an Orwellian about-face and dropped the case on the opening day of a United Nations AIDS summit in New York. He justified this with the claim that America wanted "to protect intellectual property rights without compromising . . . efforts to combat HIV/AIDS.".93

Such cant aside, the U.S.-Brazil agreement is probably more of a temporary laying down of arms than a final settlement. The agreement sets up a bilateral dialogue, and calls for Brazil to give notice if it intends to use the local working provision (a stipulation that is already required by the Brazilian statute), with the United States reserving all its rights to recommence the complaint at the WTO. Doubtless this détente serves present purposes well, but even as it was announced, the United States committed to "aggressively engage other countries that impose or maintain such [local working]

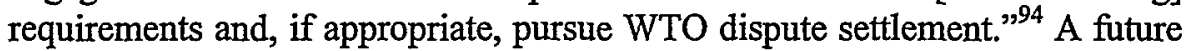
showdown over local working therefore seems inevitable, and if the political winds on AIDS should change, it could well involve Brazil again. Our argument below, while in no sense restricted to the facts of the U.S.-Brazil case or those parties as litigants, uses this case as a nominal future "dispute" for illustrative purposes.

At question is Brazil's new law for patents, the Industrial Property Law, promulgated on May 14, 1996. Its primary purpose was to implement a new patent regime that was in accordance with the TRIPS Agreement. ${ }^{95}$ One provision, however, raised the ire of the United States. According to the U.S. complaint, "Article 68 of Brazil's 1996 Industrial Property Law discriminates

89. Geoff Dyer, Brazil Defiant Over Cheap ADS Drugs, FIN. TMES, Feb. 9, 2001, at 10.

90. Stephen Buckley, U.S., Brazil Clash over AIDS Drugs: 'Model' Treatment Program Seen at Risk in Dispute on Patents and Pricing, WASH. POST, Feb. 6, 2001, at A1.

91. USTR, supra note 1.

92. Office of the United States Trade Representative 2001 Special 301 Report, (Apr. 30, 2001), at 10, available at $\mathrm{http}: / / \mathrm{www} . u s t r . g o v / e n f o r c e m e n t /$ special.pdf.

93. USTR, supra note 1. Anti-globalization and anti-ADS activists had been planning demonstrations in New York over the U.S.-Brazil case, and Brazil certainly would have been boosted by these demonstrations. The settlement seems to have been carefully timed to avoid these media spectacles.

94. Id.

95. Christopher Mayer, The Brazilian Pharmaceutical Industry Goes Walking From Ipanema to Prosperity: Will the New Intellectual Property Law Spur Domestic Investment?, 12 TEMPLE INT'L \& CoMP. L.J. 377, 387 (1998). 
against U.S. owners of Brazilian patents whose products are imported into, but not locally produced in, Brazil.",96

The text of the impugned provision says that the government can authorize a compulsory license if the patent owner does not manufacture the product in the territory of Brazil within three years of the patent grant. ${ }^{97}$ The patent holder can argue that it is not economically feasible to manufacture locally, though it is unclear if that term means unprofitable or simply not as profitable as manufacture elsewhere. A further defense for the patent owner is to argue that the local applicant for a compulsory license does not have sufficient technical and economic capability to exploit the patent.

The United States claimed that this statutory scheme violates Article $27(1)^{98}$ and Article $28(1)^{99}$ of the TRIPS Agreement. Though Article 27 is titled "Patentable Subject Matter," as noted above it also states that patent rights will be enjoyed without discrimination as to whether a product is imported or produced locally. Article 28, titled "Rights Conferred," states

96. Brazil-Measures Affecting Patent Protection, supra note 1.

97. This provision reads:

The patent owner shall be subject to compulsory licensing of his patent if he exercises his rights therein in an abusive manner or if he uses it to abuse economic power according to the law in force, under the terms of an administrative or judicial decision.

Paragraph 1 - The following may also be grounds for a compulsory licensing:

I - non-exploitation of the object of the patent within the Brazilian territory for failure to manufacture the product or failure to fully use a patented process, except in cases of economic unfeasibility, in which case importation shall be permitted; or

II - commercialization that does not satisfy the needs of the market.

Paragraph 2 - A license may be requested only by a party having a legitimate interest and having the technical and economic capability to effectively exploit the object of the patent for the purposes predominately of the internal market, in which case the exception contained in item I of the previous paragraph shall not apply.

Paragraph 5 - A compulsory license under Paragraph 1 may only be requested if 3 (three) years have elapsed since the patent was granted.

Brazilian Industrial Property Law, supra note 2, art. 68 (unpublished translation on file with the authors). Thanks to Juliano Froehner, LL.M. (Harvard), for translation.

98. The provision reads:

1. Subject to the provisions of paragraphs 2 and 3 below, patents shall be available for any inventions, whether products or processes, in all fields of technology, provided that they are new, involve an inventive step and are capable of industrial application. Subject to paragraph 4 of Article 65, paragraph 8 of Article 70 and paragraph 3 of this Article, patents shall be available and patent rights enjoyable without discrimination as to the place of invention, the field of technology and whether products are imported or locally produced.

TRIPS Agreement, supra note 3, art. 27(1).

99. The provision reads:

1. A patent shall confer on its owner the following exclusive rights:

(a) where the subject matter of a patent is a product, to prevent third parties not having the owner's consent from the acts of: making, using, offering for sale, selling, or importing for these purposes that product;

(b) where the subject matter of a patent is a process, to prevent third parties not having the owner's consent from the act of using the process, and from the acts of: using, offering for sale, selling, or importing for these purposes at least the product obtained directly by that process.

TRIPS Agreement, supra note 3, art. 28(1). 
what those basic patent rights are, including the exclusive rights to make or sell the patented product. ${ }^{100}$ Under the Brazil statute, patent owners may be deprived of those exclusive rights where they fail to manufacture locally without recognized excuse.

According to a simple reading of those articles, Article 68 of Brazil's Industrial Property Law would indeed appear to violate the TRIPS Agreement. However, this analysis is too simplistic. The TRIPS Agreement also provides specific exceptions to the rights of patentees, found in Articles 30 and 31. Bring these Articles into view, and one must also consider whether Brazil's statutory scheme is permissible under these exceptions. Article 30 allows exceptions to patent rights so long as they are limited, do not conflict with normal exploitation, and do not unreasonably prejudice the legitimate interests of the owner. It does not appear to contemplate compulsory licensing, at least for commercial use, although some observers have argued to the contrary. ${ }^{101}$ Article 31 pertains directly to compulsory licensing and is the article most likely to govern in the Brazil dispute.

Our analysis therefore turns on Article 31, its relationship with Article 27, and additionally, the implications of the Paris Convention. Only by reading these provisions as a whole can the meaning of Article 27(1) be determined. This more inclusive approach accords with established principles of treaty interpretation. Indeed, one eminent scholar cautions that " $[t]$ he text of a treaty must be read as a whole. One cannot simply concentrate on a paragraph, an article, a section, a chapter or a part." ${ }^{, 102}$ It is in this light that we conduct our analysis below.

\section{B. Article 31}

The compulsory license clause of the TRIPS Agreement, Article 31, mainly exists to control the procedures and conditions of issuing a compulsory license. With the single exception of semiconductor technology, it does not limit the grounds for doing so. As discussed in Part III, the United States tried

100. The rights are actually characterized as negative rights, not positive rights. That is, the patent owner is not given the right to make, use, or sell the product, but the right to prevent others from doing so. See id.

101. E.g., Halewood, supra note 8, at 264-71. Halewood argues that Article 30 authorizes any exception without the patentee's consent, including compulsory licenses. He acknowledges that in accordance with the text, Articles 30 and 31 must be read as mutually exclusive and that Article 31 deals explicitly with compulsory licensing. However, he suggests that the two Articles could justify different classes of compulsory licenses. Weissman says that local working requirements would be difficult to justify under Article 30 . Nevertheless, he provides a possible rationale:

An argument on behalf of work-the-patent requirements (under Article 30) would rest on two grounds. First, that promoting technology transfer is a legitimate interest of a third party, namely the country beneficiary of the transfer. Second, to the extent that work-thepatent requirements succeed at technology transfer and building up the domestic scientific base, they bring countries closer to developing their own independent research capacity. These research capacities would be directed to addressing local diseases for which the treatment, prevention, or cure does not hold out the prospect of sufficient profit to draw the interest of industrialized country pharmaceutical companies. That is, the argument would be that there is an indirect health interest in work-the-patent requirements.

Weissman, supra note 54 , at $1111-12$.

102. I.M. SincLAIR, The VIENNA CONVENTION ON THE LAW OF TREATIES 127 (2d ed. 1984). 
and failed to limit the grounds of compulsory licensing. At the last ascertainable consensus, the Brussels Draft, negotiators agreed that compulsory licensing would be an available remedy for a failure to work. Leaving open the grounds of compulsory licensing in the final TRIPS Agreement was not an error on the part of negotiators. Daniel Gervais, who participated in those negotiations, explains:

\begin{abstract}
This Article . . . sets specific conditions for the grant, but does not list or define the cases where a licence may be granted (except for semiconductor technology). Negotiators weighed both options and preferred to leave open the cases where compulsory licensing (defined here as use by governments or by third parties authorised by governments) may be allowed. ${ }^{103}$
\end{abstract}

The fact that Article 31 does not generally prohibit any grounds for compulsory licensing means that national discretion to compel a license is implicitly wide-ranging, including for a failure to work. This conclusion is amplified by the fact that, in the case of a single technology, Article 31 does depart from permissiveness and explicitly lists the grounds for which a compulsory license may be issued. Semiconductor technologies may be compulsorily licensed only "for public non-commercial use or to remedy a practice determined ... to be anti-competitive." ${ }^{\prime 104}$ By the principle of inclusio unius est exclusio alterius, ${ }^{105}$ if technologies other than semiconductors were to have their grounds of compulsory licensing similarly limited, those technologies and those grounds should also be listed in Article 31. It is significant that they are not. ${ }^{106}$

What inference can be drawn from the fact that failure to work locally is not explicitly mentioned in Article 31 ? Recall it was mentioned in an article of the Brussels Draft, ${ }^{107}$ in which negotiators agreed that compulsory licenses for failure to work were subject to essentially the same conditions as under Article 5A(4) of the Paris Convention, ${ }^{108}$ a provision that is elsewhere incorporated into the TRIPS Agreement. ${ }^{109}$ At that time, the only difference of opinion among the Brussels Draft negotiators was whether or not to include bracketed text that deemed importation to satisfy local working, whereas only

103. GERVAIS, supra note 11, at 165 ; see also discussion infra Part III.

104. TRIPS Agreement, supra note 3, art. 31(c).

105. BLACK'S LAW DICTIONARY 687 (5th ed. 1979) (defining inclusio unius est exclusio alterius as "the inclusion of one is [tacitly] the exclusion of another").

106. Elsewhere in Article 31, the only other departures from the "standard" Article 31 conditions and procedures are similarly explicit: special considerations apply to compulsory licenses issued for reasons of national emergency, TRIPS Agreement, supra note 3, art. 31(b), anti-competitive practices, $i d$. art. 31(k), and patent dependency, id. art. 31(1).

107. Brussels Draft, supra note 70 , art. 34 .

108. The provision reads :

A compulsory license may not be applied for on the ground of failure to work or insufficient working ... before the expiration of a period of four years from the date of filing of the patent application or three years from the date of the grant of the patent, whichever period expires last ...; it shall be refused if the patentee justifies his inaction by legitimate reasons .... Such a compulsory license shall be non-exclusive and shall not be transferable, even in the form of the grant of a sub-license, except with that part of the enterprise or goodwill which exploits such license....

Stockholm Revision to Paris Convention (1967), supra note 14, art. 5A(4), in BODENHAUSEN, supra note 6 , at 67.

109. TRIPS Agreement, supra note 3, art. 2(1). 
manufacture had done so before. Had the Brussels Draft article been left in with the bracketed text, then "local working" would have become enlarged over its historical meaning, such that those words would now effectively signify "local availability for sale," including by importation. On the other hand, had the same article been left in without the bracketed text, that would simply duplicate Article 5A of the Paris Convention, and there would be no change to the historical meaning of "local working" as indicating only local manufacture. But in the end, we find the whole Brussels Draft article absent from the TRIPS Agreement, bracketed text and all. This logically suggests that the parties wanted to continue the status quo ante respecting the historical meaning of "local working" because the article into which the parties would have inserted a changed meaning is simply gone. We infer that the only change effected by Article 31 of the TRIPS Agreement is to take the law in the Paris Convention governing compulsory licenses for failure to work, and to supplement it by the new requirements of Article 31 .

Indeed, Article 31 does impose many new procedural or substantive conditions. Under the new rules, each grant of a compulsory license must be considered on a case-by-case basis. ${ }^{110}$ The government must first make efforts to obtain a voluntary license. ${ }^{111}$ The patent holder must receive "adequate remuneration."112 Production must be predominantly for the domestic market. ${ }^{113}$ The license must be non-exclusive. ${ }^{114}$ Judicial review must be afforded for any decisions related to the compulsory license. ${ }^{115}$ And finally, the "scope and duration" of the license must be "limited to the purpose for which it was authorised," and must be liable to termination if the reasons underlying that authorization cease to exist. ${ }^{116}$ While these new rules certainly narrow the opportunity for countries to grant compulsory licenses for failure to work, they do not prohibit the practice.

Turning to Brazil's Industrial Property Law, all of the above requirements appear to be met. Under the Brazil statute, the patent owner can make submissions to the granting body, the National Institute for Industrial Property (INP) ${ }^{117}$ on issues such as whether there is in fact a failure to work (i.e., failure to manufacture) ${ }_{1}^{118}$ whether there are justifications therefor, ${ }^{119}$ and what should be the proper rate of remuneration. ${ }^{120}$ Further, compulsory licenses must be non-exclusive, ${ }^{121}$ production must be predominantly for the domestic market, ${ }^{122}$ and the patent owner can appeal any decision by INPI to a

110. Id. art. 31(a).

111. Id. art. 31(b).

112. Id. art. 31(h).

113. Id. art. 31(f).

114. Id. art. 31(d).

115. Id. art. 31(i).

116. Id. arts. $31(\mathrm{c}),(\mathrm{g})$.

117. Brazilian Industrial Property Law, supra note 2, art. 73.

118. $I d$. art. 73(3).

119. The patent owner can argue that it is not economically feasible to locally work the patent, that there are preparations being made for working, that the compulsory license applicant does not have the technical ability, or other "legitimate reasons." See id. art. 68, ๆ 1, cl. I; art. 68, ๆ 2; art. 69, cls. I, II. 120. Id. art. 73(6).

121. Id. art. 72.

122. Id. art. 68(2). 
court. ${ }^{123}$ The law does not provide specifically for termination of the compulsory license if the circumstances change (i.e., the patent owner commences local working) but there is no impediment to a court application on that basis.

If we conclude that local working is indeed permitted under Article 31 of the TRIPS Agreement, it would appear that Brazil's Industrial Property Law complies. However, if the text of Article 27(1) preempts the Article 31 exception, just the opposite would be true. The issue therefore remains: is Article 31 superior to Article 27(1)?

\section{Article 27(1)}

The primary argument of the United States is that Article 68 of Brazil's Industrial Property Law discriminates on the basis of local manufacture or importation. According to Article 27(1) of the TRIPS Agreement, "patent rights [shall be] enjoyable without discrimination as to ... whether products are imported or locally produced." ${ }^{224}$ As discussed earlier, this passage has no genesis in the negotiated drafts of the parties themselves, but is traceable to wording proposed by the Director General of the GATT. Nonetheless, once in the final TRIPS Agreement, and if read alone, it does seem to vindicate the U.S. case.

The relevant question is whether it can be read alone. In our view, while Article 27(1) articulates general protections for patentees' rights (including a protection against discrimination for importation), Articles 30 and 31 provide specific exceptions that are superior to those rights. In determining this hierarchy, the titles of Articles 30 and 31 are of some guidance: if Article 27(1) sets down the ground rule that "patent rights [shall be] enjoyable without discrimination as to . . . whether products are imported or locally produced," Article 30 follows with the title "Exceptions to [Patent] Rights Conferred," 125 and Article 31 bears the title of "Other Use Without Authorization of the [Patent] Right Holder." ${ }^{, 26}$ The meaning of "other use" is defined in a footnote to the TRIPS Agreement as "use other than that allowed under Article 30," indicating that the two Articles are concurrent and independent. ${ }^{127}$

Reading these provisions together, Article 30 sets out a first tier of eponymous "exceptions" to the "patent rights" referred to in Article 27(1), while Article 31 sets out a second tier of exceptions more liberally called "other use." Something that is "other" is, to all reasonable interpretation, little different from an "exception." Consequently, in our view, both Articles 30 and 31 express rules other than the usual rules, which are contained in Articles 27 and 28.

The same conclusion can be reached using the standard canons of WTO treaty interpretation. The WTO Dispute Settlement Understanding provides

123. Id. art. $73(8)$.

124. TRIPS Agreement, supra note 3, art. 27(1).

125. Id. art. 30 (italics added).

126. Id. art. 31 (italics added).

127. Id. art. 31 n.7. 
that conflict of provisions should be clarified "in accordance with customary rules of interpretation of public international law." 128 One such rule is expressed in the maxim lex specialis derogat legi generali, which provides in essence that where a general legal provision conflicts with a specific legal provision, the specific legal provision governs. ${ }^{129}$ Consequently, if local working laws can be justified under one of the specific exceptions (Articles 30 or 31 ), they supercede the general provision of Article 27(1).

Further interpretive assistance can be found by looking at the Vienna Convention on the Law of Treaties and the principle that the terms of a treaty such as the TRIPS Agreement should be interpreted "in the light of [the treaty's] object and purpose."130 Thus Article 27(1) should be interpreted in light of Article 7, entitled "Objectives":

\begin{abstract}
The protection and enforcement of inteliectual property rights should contribute to the promotion of technological innovation and to the transfer and dissemination of technology, to the mutual advantage of producers and users of technological knowledge and in a manner conducive to social and economic welfare, and to a balance of rights and obligations. ${ }^{131}$
\end{abstract}

Further, Article 8, titled "Principles," states:

Appropriate measures, provided that they are consistent with the provisions of this Agreement, may be needed to prevent the abuse of intellectual property rights by right holders or the resort to practices that unreasonably restrain or adversely affect the international transfer of technology. ${ }^{132}$

Both of these provisions make it abundantly clear that a transfer of technological expertise and knowledge should be achieved by domestic patent systems. Manufacturing a patented product locally is recognized as a direct method of technology transfer because it develops expertise in local workers and researchers. ${ }^{133}$ This is supportive of the stated purposes and objectives of the TRIPS Agreement.

If the above makes out a purposive interpretation in the positive sense, there also exists a negative sense: Article $5 \mathrm{~A}(2)$ of the Paris Convention, which is incorporated by reference into the TRIPS Agreement, ${ }^{134}$ deems that "failure to work" (which, in the historical sense, is failure to manufacture) is an "abuse" in law for which the remedy is a compulsory license. ${ }^{135}$ Article 8

128. Understanding on Rules and Procedures Goveming the Settlement of Disputes, Apr. 15, 1994, WTO Agreement, Annex 2, art. 3, in LEGAL TEXTS, supra note 3, at 355.

129. For an example of a WTO panel explaining and applying this principle, see Panel Report on Indonesia-Certain Measures Affecting the Automobile Industry, WTO Doc. WT/DS64/R, I 14.28 \& n.649 (July 2, 1998), available at http://www.wto.org.

130. Vienna Convention on the Law of Treaties, supra note 23, art. 31(1) (stating that "[a] treaty shail be interpreted in good faith in accordance with the ordinary meaning to be given to the terms of the treaty in their context and in the light of its object and purpose." (emphasis added)). For further discussion on the role of a treaty's object and purpose in its interpretation, see AUST, supra note 23, at 188 , and SINCLAIR, supra note 102, at 130-31.

131. TRIPS Agreement, supra note 3, art. 7.

132. Id. art. 8(2).

133. For historical view and development, see discussion supra Part II, supra note 22, and supra text accompanying notes 58-59.

134. TRIPS Agreement, supra note 3, art. 2 (stating that "Members shall comply with Articles $1-12$ and 19 of the Paris Convention (1967)').

135. The provision reads: 
of the TRIPS Agreement in turn states that a country may prevent an "abuse of intellectual property rights" by resort to "appropriate measures . . . consistent with the provisions of [the TRIPS] Agreement." The presumption of consistent usage to the word "abuse" therefore strongly suggests that the "appropriate measures" referred to in Article 8 should include compulsory licensing, consistent with Article 31.

The above arguments all confirm the proposition that, at least insofar as local working goes, Article 31 takes precedence over and derogates from Article 27(1). ${ }^{136}$ Needless to say, this view has its opponents. The United States and Switzerland, for example, are on record before a past WTO Panel for precisely the opposite view-that Article 27(1) is absolute and nonderogable by Article 31, and that any other interpretation would "violate fundamental precepts of treaty interpretation," notably by "reducing [Article 27(1)] to redundancy or inutility." 137 The Panel deciding that case concurred in that interpretation, but, very curiously, it did so on the basis that it is "understood" and an "acknowledged fact" that Article 31 is subordinate to Article 27(1) "without the need for any textual provision so providing."138

The Panel decision on this point is extraordinarily tendentious, and no better than a bare assertion. One can place very little confidence in a decision which, by its own admission, was arrived at "without the need" of consulting the TRIPS Agreement text. ${ }^{139}$ We argue that the Panel's interpretation is certainly wrong.

Each country of the Union shall have the right to take legislative measures providing for the grant of compulsory licenses to prevent the abuses which might result from the exercise of the exclusive rights conferred by the patent, for example, failure to work.

Stockholm Revision to Paris Convention (1967), supra note 14, art. 5A(2), in BODENHAuSEN, supra note 6 , at 67 .

136. One notable difference is that in relying on Article 5A(2) of the Paris Convention, no general proposition need be decided about whether or not Article 31 more generally takes precedence over Article 27(1). The "abuses" defined by Article 5A(2) of the Paris Convention pertain to failure to work and thus discrimination as between imported or locally produced products; the other heads of nondiscrimination in Article 27(1) are unaffected. Accordingly, reasoning on the basis of the Paris Convention need not open the door to Article 31 trumping, for instance, nondiscrimination as respects the field of technology of an invention.

137. Panel Report on Canada-Patent Protection of Pharmaceutical Products, supra note 16, I 5.36(b)(i). The case involved Canadian patent laws that allowed stockpiling and regulatory review of pharmaceutical products, without the consent of the patent holder prior to the expiration of the patent term. It was alleged by the European Community that this treated the pharmaceutical industry in a discriminatory fashion, contrary to Article 27(1). Canada pleaded that the law was a permissible exception under Article 30. For further discussion of this case, see Sue Ann Mota, TRIPS-Five Years of Disputes at the WTO, 17 ARIZ. J. OF INT'L \& COMP. L. 533, 545 (2000).

138. Panel Report on Canada-Patent Protection of Pharmaceutical Products, supra note 16, ๆ 7.91 .

139. None of which is to say that the United States and Switzerland did not attempt submissions based on the TRIPS Agreement text. The United States submitted that the "patent rights" which must be enjoyable without discrimination under Article 27(1) are not the same "rights conferred" by a patent according to Article 28, and that the exception in Article 31 applies only to the latter, not the former. Switzerland submitted that, if Article 27(1) were not meant to be absolute, the restrictions to it "would have been expressly written down," for instance, in a fuller "Subject to ..." preface that listed every article which would take precedence over it. The Panel ruled on neither submission, and instead preferred to find that the nondiscrimination rules of Article 27(1) trumped Article 31 while rejecting guidance from the TRIPS Agreement text. See Panel Report on Canada-Patent Protection of Pharmaceutical Products, supra note 16, 891 5.28, 5.36(3). 
On closer analysis, it is not true that Article 27(1) must be set at naught and reduced to "redundancy or inutility" where it is derogable by Article 31 . In a dispute over the validity of local working, the central stricture of Article $27(1)$ is that "patent rights [must be] enjoyable without discrimination as to . . . whether products are imported or locally produced." But discrimination, which is prohibited, stands in distinction to differential treatment, which is not. Rather, discrimination in law ordinarily consists of the subset of differential treatment that is "unjustified" or arbitrary (i.e., a difference maintained without relevant reasons). ${ }^{140}$ Accordingly, differential treatment as between imported and locally produced products need not be discriminatory, and can even be remedial, if there are legitimate reasons therefor. ${ }^{141}$

In sorting out which differential treatment is legitimate, and which is arbitrary and discriminatory, surely the "Objectives" and "Principles" stated in Articles 7 and 8 of the TRIPS Agreement must be determinative. Thus it should not be arbitrary to imagine Article 27(1) being derogable by Article 31, where Article 31 is used to grant a compulsory license to remedy failure to work, thus securing the benefits of "technological development" and "the transfer and dissemination of technology." "142 Alternatively, if one takes the view that this would be arbitrary, then other cases of remedial differential treatment almost certainly are as well. For example, laws for pharmaceutical patent extension, which give these products extra years of patent protection relative to other fields of technology, are equally suspect. ${ }^{143}$ Faced with the right economic incentives, it would seem that every country can agree that

140. As regards discrimination in the TRIPS Agreement context, see Panel Report on Canada-Patent Protection of Pharmaceutical Products, supra note 16, I 7.94, which states that the "unjustified imposition" of differential treatment is a hallmark of discrimination, and that discrimination "certainly extends beyond the concept of differential treatment." This accords with the U.S. submission that "not all differential treatment is "discrimination." Id. I 7.100. For discrimination as considered under other WTO agreements, see the cases cited in id. ๆ 7.98 n.436.

141. As the United States submitted, "In some circumstances, differential treatment could actually restore parity in the enjoyment of patent rights rather than resulting in discrimination." Panel Report on Canada-Patent Protection of Pharmaceutical Products, supra note 16, $\mathbb{1}$ 5.36(3).

142. Correa suggests a similar interpretation:

A possible option is to provide-in line with Article 8.1 of the TRIPS Agreement-for the granting of compulsory licenses in qualified cases of local working, for instance, when such a lack affects the commercial or industrial development in the country of sectors of vital interest.

CORREA, supra note 20 , at 9.

143. The rationale behind extending patent protection for pharmaceuticals is that subjecting products entering commerce to time-consuming regulatory requirements in effect subtracts several years from the nominal twenty years of market exclusivity that a patent confers. Laws such as the U.S. Patent Term Restoration Act offer pharmaceutical patents differential, more generous treatment to remedy this situation, and may be worth hundreds of millions (or even billions) of dollars to patent holders. See 35 U.S.C. $\$ \S 155-56$ (2001). While it is certainly true that countries may adopt more extensive patent protection than the TRIPS Agreement requires, doing so is only allowed where this "does not contravene the provisions of [TRIPS]." See TRIPS Agreement, supra note 3, art. 1(1). Assuming then for the sake of argument that pharmaceutical patent term extension is valid, Article 1(1) must take precedence over and derogate from Article 27(1); and if this is so, it becomes untenable that Article 27(1) is absolute and not similarly derogable by Article 31 . The fates of local working and pharmaceutical patent term extension are therefore very closely linked. Canada requested consultations at the WTO with respect to the European Community's patent extension scheme, but the matter was not later pursued. See Permanent Mission of Canada Concerning European Communities-Patent Protection for Pharmaceutical and Agricultural Chemical Products, WTO Doc. WT/DS153/IIP/D/G/L/283 (Dec. 7, 1998), available at http://www.wto.org. 
some degree of differential treatment is legitimate; and it is even arguable that differential treatment that is arbitrary in a rich country may be legitimate in a developing one, or vice versa. ${ }^{144}$ Thus, acknowledging legitimate instances of differential treatment, which can be remedied by Article 31, does not set Article 27(1) at naught, but leaves it undiminished to forbid arbitrary instances of discrimination (e.g., a hypothetical law which capped damages for patent infringement at $\$ 1$, where the infringed product is imported and not locally manufactured).

To summarize, the weight of interpretive guidance consistently indicates that Article 31 can take precedence over Article 27(1). This guidance includes the titles of the exceptions in Articles 30 and 31; the well-established rule of lex specialis derogat legi generali; the principle in the Vienna Convention, which seeks conformity to the objectives and principles of the TRIPS Agreement as a whole; the definition of failure to work as an "abuse" at law, for which the Paris Convention (and the TRIPS Agreement by incorporation) prescribes compulsory licensing as a remedy; the interpretation of Article 27(1) as prohibiting discrimination, but not all differential treatment; and, finally, notwithstanding all else, resort to the travaux préparatoires, which hardly evince a shining consensus among the parties to alter the centuries-old practice of local working. Against all this is the contrary guidance that Article $27(1)$ is absolute and prohibits all measures differentiating between locally produced and imported goods - a proposition that, while it may be the law in one Panel decision, is admitted by the Panel to lack any textual support in the TRIPS Agreement. On the whole, the weight of guidance is more supportive of the theory that local working requirements are permitted by the TRIPS Agreement, and the opposing view to us seems very unlikely.

\section{CONCLUSION}

It has correctly been said before that the TRIPS Agreement was written by "diplomats, not lawyers," and the extent to which it today challenges us with interpretational puzzles is closely related to that awkward birth. ${ }^{145}$ The final draft is a recycling of ideas advanced by Director General Dunkel and arbitrated by Chairman Anell, and, as Daniel Gervais notes, "there is no record of the most important part of the deliberations, [being] the informal sessions during which progress was made [by negotiators] on successive versions of the Chairman's text." ${ }^{\text {p146 }}$ History is the loser for this, and it is accordingly difficult to understand precisely what the negotiators intended or understood.

144. In this light, a useful analogy might be the legal principle of "substantive equality," or what Americans call "affirmative action." A developing country such as Brazil might, consistent with the Objectives and Principles of Articles 7 and 8, be entitled to some leeway in Article 27(1) to enforce local working. This flows from the fact that developing countries start at an economic disadvantage, and so differential treatment might be remedial in these circumstances. The same rationale would not apply if, say, wealthy Japan tried to do likewise.

145. GeRVAIS, supra note 11, at 27, citing Friedl Weiss, International Public Law Aspects of TRIPS, in TRADE-RELATED ASPECTS OF COPYRIGHT 16 (H. Cohen Jehoram et al. eds., 1996).

146. GeRvaIS, supra note 11 , at ix. 
Nevertheless, the ambiguity of the final draft probably satisfied all the parties, because they could all claim it said exactly what they wanted it to say. This is occasionally the consequence of irreconcilable positions in treaty negotiation:

\begin{abstract}
The natural desire of negotiators to bring negotiations to a successful conclusion will often result in the adoption of vague or ambiguous formulations. Sometimes the parties will have deliberately wished to avoid too much precision in order to allow themselves in the future to argue that the provision as formulated does not commit them to an inconvenient or too onerous obligation. ${ }^{147}$
\end{abstract}

When a WTO Panel or Appellate Body finally deals squarely with the local working issue, it should be mindful of this lack of consensus, and should be appropriately skeptical of wishful interpretations touted by one litigant or the other. In the absence of a full, clear record of the parties' intentions, the usual canon of interpretation of international law is much more reliable than litigants' idle conjectures.

The trouble is cases have been won on conjecture and wishful thinking before: recall the Panel which swept aside a contentious interpretation of Articles 27(1) and 31 as merely "understood."148 This was an error. A Panel in similar straits would do well to recall the Appellate Body, which has said that the unwritten expectations of one party cannot be used to change what is, or is not, in the text:

\begin{abstract}
The legitimate expectations of the parties to a treaty are reflected in the language of the treaty itself. The duty of a treaty interpreter is to examine the words of a treaty to determine the intentions of the parties. This should be done in accordance with the principles of interpretation set out in Article 31 of the Vienna Convention. But these principles of interpretation "neither require nor condone the imputation into a treaty of words that are not there or the importation into a treaty of concepts that were not intended."149
\end{abstract}

We agree wholeheartedly with the Appellate Body: the correct approach is to look to the treaty's text-the actual words of the TRIPS Agreement. This may be supplemented by canon and principles of interpretation in international law, such as those in the Vienna Convention, and reference to the travaux préparatoires, which may or may not shed light on intention where there is lingering ambiguity. What must never be done is to accept the submission of a party as to interpretation, where the party cannot raise these species of proof.

Finally, some comment is appropriate as to the possible aftermath of a future WTO decision (we would say an incorrect one) flatly prohibiting local

147. SnCLAIR, supra note 102 , at 142 .

148. See Panel Report on Canada-Patent Protection of Pharmaceutical Products, supra note 16, ๆ 7.91; and text accompanying supra note 138.

149. Appellate Body Report on India-Patent Protection for Pharmaceutical and Agricultural Chemical Products, supra note 19, I 45. One scholar notes that, "the decision conveys the firm message that the Appellate Body does not intend to be persuaded by arguments about what the parties to the Agreement thought it meant-or expected it to mean-but somehow failed to mention." Frederick M. Abbott, TRIPS in Seattle: The Not-So-Surprising Failure and the Future of the TRIPS Agenda, 18 BERKELEY J. INT'L L. 165, 175 (2000). 
working. For whoever may be successful in such a dispute may enjoy a pyrrhic victory.

Here is how. Recall that the U.S. pleading against Brazil's patent law did not impugn Brazil's right to issue a compulsory license-that much is of course incontrovertible. Rather, the U.S. pleading impugned only the grounds on which Brazil would do so (i.e., a failure to work locally), which the United States submitted is discriminatory. Given that pleading, a favorable Panel ruling would not invalidate the outcome of compulsory licensing, but merely the grounds by which that outcome is reached. What, then, is to prevent Brazil from re-legislating, so as to delete the offending, discriminatory grounds of failure to work from its law, while replacing that provision with an openended discretion to issue compulsory licenses? Such a move would simultaneously cure the U.S. complaint, while arming Brazil with an even more wide-ranging power to grant compulsory licenses than before. In short, the Brazilians could do more harm to U.S. interests with such a law, although it would be less suspect under the TRIPS Agreement!

Strange as it sounds, this is true. Even if we assume, for the sake of argument, that Article 27(1) is paramount, non-derogable, and imposes limitations of nondiscrimination on the exercise of Article 31, none of this forbids a law purporting to grant compulsory licenses in the "public interest." Of course, there might be questions later if the wide discretion granted by that law were exercised discriminatorily, but that is a separate matter concerning the legitimacy of administrative decisions, rather than the substantive law itself. So far as the statute itself goes, what is to prevent Brazil from amending its law to read exactly like Section 24 of the German Patent Law:

\footnotetext{
If the ... patentee refuses to permit the exploitation of the invention by another... offering to pay reasonable compensation and to furnish security therefor, that person shall be given authority to exploit the invention if the permission is indispensable to the public interest. $^{150}$
}

Permitting compulsory licensing on public interest grounds such as these is not irregular; at least nine of twelve Western European countries do so. ${ }^{151}$ The Brazilian courts would likely have little difficulty in determining that technology transfer, economic development, and possibly even cheap AIDS drugs, are "indispensable to the public interest"-all this and more could fit that elastic criterion. Far from conferring excessive latitude, a compulsory licensing law based on the public interest comports with the WTO Ministers' recent Doha Declaration, which states that WTO members have "freedom to determine the grounds upon which [compulsory] licenses are granted." ${ }^{, 152}$ As an added bonus, such an amendment would let the Brazilian government grant compulsory licenses for the public interest immediately, without the three- to four-year wait that Article $5 \mathrm{~A}(4)$ of the Paris Convention requires when remedying a failure to work.

150. Julian-Arnold, supra note 7, at 379.

151. See HANSEN \& HIRSCH, supra note 7, at 407 .

152. Declaration on the TRIPS Agreement and Public Health, WTO Doc. WT/MIN(01)/DEC/2, I 5(b) (Nov. 14, 2001), available at http://www.wto.org. 
Thus, an amendment of this kind would make Brazil's power to issue a compulsory license: (1) broader, (2) swifter, (3) consistent with much of European patent law, and (4) totally immune from a challenge of the kind raised by the United States under the TRIPS Agreement. There seem to be no disadvantages.

Bearing all this in mind, the United States and other WTO members should concede that any grievance against local working requirements is probably not worth fighting. Any member risking a fight might get exactly what it asks for: the end of local working requirements, but in their place, far more aggressive "public interest" compulsory licensing laws. Or the challenging member might trigger a trade war, where the respondent member targets other instances of differential treatment, such as laws for pharmaceutical patent extension. American industries could not possibly relish these outcomes, nor would the U.S. Trade Representative be very popular for procuring them. The next time a dispute arises, a bit more circumspection might be in order before the Americans chase the Brazilians and their patent law to Geneva. 
